\title{
Effect of Zr Addition on Overaging and Tensile Behavior of 2618 Aluminum Alloy
}

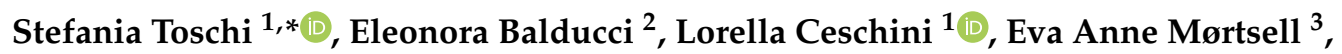 \\ Alessandro Morri ${ }^{4}\left(\mathbb{D}\right.$ and Marisa Di Sabatino ${ }^{3}$ \\ 1 Department of Civil, Chemical, Environmental and Materials Engineering (DICAM), University of Bologna, \\ Viale Risorgimento 4, 40136 Bologna, Italy; lorella.ceschini@unibo.it \\ 2 Ferrari Auto SpA, Via Abetone Inferiore 4, 41053 Maranello, MO, Italy; eleonora.balducci@ferrari.com \\ 3 Department of Materials Science and Engineering, Alfred Getz vei 2, Norwegian University of Science and \\ Technology, 7491 Trondheim, Norway; eva.mortsell@hydro.com (E.A.M.); \\ marisa.di.sabatino.lundberg@ntnu.no (M.D.S.) \\ 4 Department of Industrial Engineering (DIN), University of Bologna, Viale Risorgimento 4, 40136 Bologna, \\ Italy; alessandro.morri4@unibo.it \\ * Correspondence: stefania.toschi3@unibo.it; Tel.: +39-051-209-3462
}

Received: 22 December 2018; Accepted: 22 January 2019; Published: 26 January 2019

\begin{abstract}
The effect of $\mathrm{Zr}$ addition on overaging and tensile behavior in a $2618 \mathrm{Al}-\mathrm{Cu}-\mathrm{Mg}-\mathrm{Ni}-\mathrm{Fe}$ alloy has been investigated in this study. The chemical composition of the base 2618 alloy, containing $\sim 0.1 \mathrm{wt} \%$ of $\mathrm{Zr}$, was modified by adding $\mathrm{Zr}$ to reach the target content of $0.25 \mathrm{wt} \%$. Cast bars were T6 heat-treated according to industrial parameters, involving soaking at $525^{\circ} \mathrm{C}$ for $8 \mathrm{~h}$, quenching in hot water $\left(50{ }^{\circ} \mathrm{C}\right)$, and artificial aging at $200^{\circ} \mathrm{C}$ for $20 \mathrm{~h}$. Both the T6 2618 and $2618+\mathrm{Zr}$ alloys were overaged at 250 and $300^{\circ} \mathrm{C}$ for up to $192 \mathrm{~h}$, to evaluate the decrease in hardness with high temperature exposure time. The tensile behavior of the alloys was investigated in the overaged condition, both at room temperature and at $250{ }^{\circ} \mathrm{C}$. The microstructure of the as-cast and solution-treated samples was investigated by optical and scanning electron microscopy, while the precipitate microstructure at the nanoscale was analyzed by transmission electron microscopy in overaged condition. Experimental data revealed that the presence of $0.25 \mathrm{wt} \% \mathrm{Zr}$ does not induce modifications at the macroscale on the microstructure of 2618 alloy while, at the nanoscale, the presence of Zr-based precipitates was observed. The overaged $\mathrm{Zr}$-enriched alloy showed increased yield and ultimate tensile strength in comparison to the base alloy, at equal heat treatment condition, both at room temperature and $250{ }^{\circ} \mathrm{C}$.
\end{abstract}

Keywords: aluminum alloy; 2618; zirconium; overaging; high temperature; microstructure; tensile behavior

\section{Introduction}

Aluminum alloys, thanks to the elevated specific strength and hardness associated with excellent processing properties, are widely used as structural materials in the automotive sector. Recent trends in engine design, driven by the need of reducing fuel consumption and gas emission, led to the need of lighter alloys accompanied with enhanced mechanical properties. Pistons are among the engine parts which are heavily exposed to mechanical and thermal stresses and, as a result of the downsizing trend of engines, are in constant need of further improvement.

Local working temperature close to $300^{\circ} \mathrm{C}$ may be reached in diesel engines or high performance engines [1,2]. In such extreme conditions, strengthening precipitates formed during alloy heat treatment undergo dissolution and coarsening phenomena. Consequently, the precipitate distribution will be less effective in hindering dislocation motion during material deformation, thus leading to 
a decrease in tensile and fatigue properties. In view of this, new strategies to increase the thermal stability of aluminum alloys are needed.

One of the most common alloys for the production of forged high-performance pistons is the 2618 alloy, which contains $\mathrm{Cu}$ and $\mathrm{Mg}$ as its primary alloying elements. In the 2618 alloy, the high strength and high thermal stability are achieved by a combination of precipitation and dispersion strengthening. Fe and $\mathrm{Ni}$ are usually present at a 1:1 atomic ratio to generate $\mathrm{Al}_{9} \mathrm{FeNi}$ primary and coarse dissolution-resistant particles [3,4]. The heat treatment is generally applied to strengthen the alloy by exploitation of solute elements through precipitation hardening, inducing the formation of ternary S-phases, $\mathrm{Al}_{2} \mathrm{CuMg}$ [5].

When the enhancement of thermal stability is of major concern, a high-volume fraction of evenly distributed coarsening-resistant particles should be obtained by heat treatment. Intermetallic phases, thanks to the high thermal stability, are the most promising candidates for strengthening of heat resistant $\mathrm{Al}$ alloys [6-12]. $\mathrm{Al}_{3} \mathrm{M}$-type intermetallic precipitates are particularly attractive in this respect $[7,13]$. Transition elements, such as Ti, Zr, Hf, V, generating trialuminides, have low diffusion coefficients in $\mathrm{Al}$ and are, therefore, suitable candidates to enhance the alloys' thermal stability [7]. Primary precipitation during casting operations and uneven distribution of precipitates between outer and inner dendritic regions should be avoided, aiming to exploit the effect of such solute elements [14-16]. It should also be taken into account that, in comparison to the typical age-hardening precipitate phases, which precipitate at temperatures in the range of $150-200{ }^{\circ} \mathrm{C}$ due to their low diffusion rates in $\mathrm{Al}, \mathrm{Al}_{3} \mathrm{M}$ transition element trialuminides generally nucleate in solid solution at quite high temperatures $\left(350-500{ }^{\circ} \mathrm{C}\right.$ ). In the specific case of $\mathrm{Zr}$, the precipitation of spheroidal nanometer-scale $\mathrm{Al}_{3} \mathrm{Zr}$ was reported to start between 400 and $425^{\circ} \mathrm{C}$ in binary $\mathrm{Al}-\mathrm{Zr}$ and complex alloys $[17,18]$. On the other hand, due to the low diffusivity, such phases are reported to maintain a high strengthening effectiveness at temperatures close to $400{ }^{\circ} \mathrm{C}$ [17-19]. It should be mentioned that the 2618 alloy generally contains small amounts of $\mathrm{Zr}$ to increase the alloy recrystallization resistance.

The aim of the present work was to assess the effect of increasing $\mathrm{Zr}$ content from $\sim 0.1 \mathrm{wt} \%$ to $\sim 0.25 \mathrm{wt} \%$ on the thermal stability of 2618 , whose overaging behavior was previously studied by the authors [20]. In particular, the aim was to evaluate if a typical industrial heat treatment cycle, combined with the addition of $\mathrm{Zr}$, could lead to an increase in the overaging response, including the room and high temperature tensile behavior.

\section{Materials and Methods}

Castings of the base- and $\mathrm{Zr}$-enriched $2618 \mathrm{Al}$ alloy were produced in a laboratory induction furnace (TVC 10S, Topcast Engineering, Arezzo, Italy) by permanent mold casting. The 2618 alloy was molten at $800{ }^{\circ} \mathrm{C}$ in a protective $\mathrm{Ar}$ atmosphere; for the production of $\mathrm{Zr}$-enriched castings (hereafter referred to as $2618+\mathrm{Zr}$ ), a proper amount of $\mathrm{Al}-10 \mathrm{wt} \% \mathrm{Zr}$ master alloy was added to the molten base alloy, aiming to reach the target $\mathrm{Zr}$ amount (i.e., $0.25 \mathrm{wt} \%$ ). In this case, the temperature was raised to $900{ }^{\circ} \mathrm{C}$ for $30 \mathrm{~min}$ to foster master alloy dissolution. The temperature was then decreased to $800{ }^{\circ} \mathrm{C}$ by $10{ }^{\circ} \mathrm{C}$ steps every $5 \mathrm{~min}$. The alloys were then cast into pre-heated steel molds kept at $250{ }^{\circ} \mathrm{C}$ to obtain cylindrical bars, with a diameter of $10 \mathrm{~mm}$.

Chemical composition of the castings was checked by Glow Discharge Optical Emission Spectroscopy (GDOES: GDA-650, Spectruma Analytik GmbH, Hof, Germany). Table 1 summarizes the average composition of 2618 and $2618+\mathrm{Zr}$.

Table 1. Chemical composition of 2618 and $2618+\mathrm{Zr}$ castings, measured by GDOES.

\begin{tabular}{ccccccccc}
\hline Element (wt \%) & $\mathbf{C u}$ & $\mathbf{M g}$ & $\mathbf{N i}$ & $\mathbf{F e}$ & $\mathbf{Z r}$ & $\mathbf{S i}$ & Ti & Al. \\
\hline 2618 & 2.146 & 1.243 & 0.992 & 0.876 & 0.119 & 0.111 & 0.092 & Bal. \\
$2618+\mathrm{Zr}$ & 2.081 & 1.165 & 0.981 & 0.865 & 0.281 & 0.118 & 0.088 & Bal. \\
\hline
\end{tabular}


The 2618 and $2618+\mathrm{Zr}$ alloys were heat-treated to the T6 temper according an industrial heat treatment procedure consisting in (i) soaking at $525^{\circ} \mathrm{C}$ for $8 \mathrm{~h}$, (ii) quenching in water at $50{ }^{\circ} \mathrm{C}$, and (iii) artificial aging at $200{ }^{\circ} \mathrm{C}$ for $20 \mathrm{~h}$.

Aiming to assess the effect of chemical modification on mechanical behavior after prolonged exposure to high temperature, overaging curves at 250 and $300{ }^{\circ} \mathrm{C}$ were obtained by soaking the T6 alloys at the abovementioned temperatures for up to $192 \mathrm{~h}$. Brinell hardness was measured at fixed time intervals by using a hardened steel ball indenter with a diameter of $2.5 \mathrm{~mm}$ and $62.5 \mathrm{~kg}$ load (HB10 scale), according to ASTM E10-08 standard [21].

The microstructure of 2618 and $2618+\mathrm{Zr}$ was investigated by optical microscope (OM: Axio Imager, Zeiss, Oberkochen, Germany) and scanning electron microscope (SEM: Evo-50, Zeiss, Oberkochen, Germany) equipped with energy dispersive X-ray spectroscopy probe (EDS: Oxford Instruments, Abingdon, UK). The secondary dendrite arm spacing (SDAS) was calculated by image analyses carried out on optical micrographs: for each cast alloy, 15 OM images at $50 \times$ magnification were used by measuring, in each field, 10 lines. Metallographic samples were prepared according to standard techniques, ground by sandpaper up to 1200 grit, then polished by diamond suspensions of 9,3 , and $1 \mu \mathrm{m}$.

In order to characterize the presence of Zr-based phases, transmission electron microscopy (TEM) analysis was carried out on overaged samples (after T6 and soaking at $300{ }^{\circ} \mathrm{C}$ for $192 \mathrm{~h}$ ) of 2618 and $2618+$ Zr. Foils were prepared from the samples by mechanical grinding to $100 \mu \mathrm{m}$ thin foils. Disks of $3 \mathrm{~mm}$ diameters were stamped out from the foils and then subsequently electropolished at $20 \mathrm{~V}$ using a Struers TenuPol-5 unit and an electrolyte containing one-third $\mathrm{HNO} 3$ and two-thirds $\mathrm{CH} 3 \mathrm{OH}$, cooled down to $-25{ }^{\circ} \mathrm{C}$ during electropolishing. TEM images were acquired in a TEM-2100F microscope (TEM: JEOL, Tokyo, Japan), operating at $200 \mathrm{kV}$. All images are taken along one of the $<110>\mathrm{Al}$ zone axes.

Tensile behavior of the investigated alloys was evaluated both at room temperature and $250{ }^{\circ} \mathrm{C}$, in an overaged condition (OA). Round dog-bone tensile specimens $\left(L_{0}=25 \mathrm{~mm}\right.$, gauge diameter $d_{0}=5 \mathrm{~mm}$ ) were machined from 2618 and $2618+\mathrm{Zr}$ castings, T6 heat-treated, and soaked at $250{ }^{\circ} \mathrm{C}$ for $48 \mathrm{~h}$ before tensile tests. The aim was to evaluate possible effects on overaging of $\mathrm{Zr}$ addition. Tensile tests were carried out on a screw-testing machine (designed by University of Bologna and manufactured by ItalSigma, Forlì, Italy) equipped with a resistance furnace and extensometer for high temperature testing, according to [22,23]. Tensile samples for tests at $250{ }^{\circ} \mathrm{C}$ were kept in the furnace for $60 \mathrm{~min}$ to homogenize the temperature of the sample before running the test. For each condition, at least three specimens were tested. Tensile properties were obtained from the data acquisition system and calculated as the average of the three tested samples. Fractographic analyses were carried out on tensile fracture surfaces by means of SEM-EDS to assess the morphology of fracture surfaces.

\section{Results and Discussion}

\subsection{Microstructure}

In the as-cast condition, both the 2618 and the $2618+\mathrm{Zr}$ alloy present a typical dendritic structure, characterized by $\alpha$-Al dendrites surrounded by intermetallic phases network (Figure 1 ). The average SDAS of 2618 and $2618+Z r$ castings is $28 \pm 5 \mu \mathrm{m}$ and $25 \pm 6 \mu \mathrm{m}$, respectively.

At the macroscale, no relevant difference was observed in coarse intermetallic phases between the two alloys. This should be ascribed to the fact that no precipitation of Zr-based primary phases occurred during solidification, thanks to the rapid cooling from the molten state obtained by permanent mold casting. Table 2 shows the chemical composition of the most common intermetallic particles found in as cast 2618 and $2618+\mathrm{Zr}$; the corresponding suggested formula is proposed by comparing SEM-EDS results and existing literature data $[5,24,25]$. Most of the intermetallic phases that were found (shown in Figure 2) are aluminide particles of $\mathrm{Al}_{x} \mathrm{FeNi}$ type. The $\mathrm{Fe}-\mathrm{Ni}$ ratio, as observed by SEM-EDS analyses, is close to 1 ; the stoichiometry is therefore in good agreement 
to the well-known $\mathrm{Al}_{9} \mathrm{FeNi}$ formula proposed in literature [4,24-26]. Fe-Ni intermetallics, hard and insoluble phases, limiting grain growth during solution treatment and high temperature working conditions, are known to induce a good thermal stability in 2618 alloy $[4,5,26,27]$. It should be pointed out that, despite a similar chemical composition, the $\mathrm{Al}_{9} \mathrm{FeNi}$ phases found in alloys $2618+\mathrm{Zr}$ seem to present a typical interconnected skeleton-like morphology while, in alloy 2618, such phases exhibit a fragmented appearance. Other minor detected phases were $\mathrm{Cu}$-bearing $\mathrm{Al}_{7} \mathrm{Cu}_{4} \mathrm{Ni}_{1} \mathrm{Al}_{7} \mathrm{Cu}_{2}(\mathrm{Fe}, \mathrm{Ni})$, and $\mathrm{Al}_{2} \mathrm{Cu}$ round particles. $\mathrm{Mg}$-containing phases, likely $\mathrm{Mg}_{2} \mathrm{Si}$ particles, were observed in both of the as-cast microstructures.
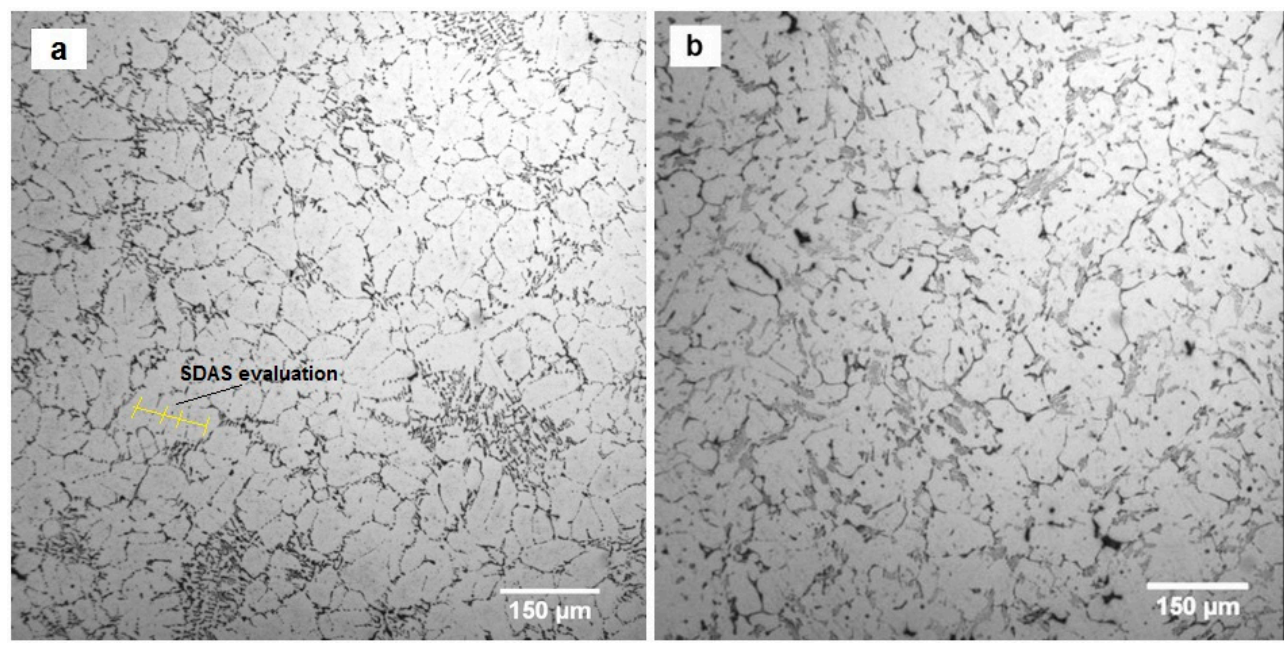

Figure 1. Optical micrographs of as-cast (a) 2618 and (b) $2618+\mathrm{Zr}$ alloy showing $\alpha$-Al dendrites surrounded by a network of intermetallic phases.

Table 2. Chemical composition (atom \%) of intermetallic particles observed on 2618 and $2618+\mathrm{Zr}$ as-cast samples, measured by SEM-EDS.

\begin{tabular}{ccccccc}
\hline $\mathbf{A l}$ & $\mathbf{M g}$ & $\mathbf{S i}$ & $\mathbf{F e}$ & $\mathbf{N i}$ & $\mathbf{C u}$ & Suggested \\
\hline 80.16 & - & 0.35 & 8.33 & 9.47 & 1.69 & $\mathrm{Al}_{9} \mathrm{FeNi}$ \\
61.57 & - & - & 0.68 & 7.15 & 30.60 & $\mathrm{Al}_{7} \mathrm{Cu}_{4} \mathrm{Ni}$ \\
72.60 & 0.40 & - & 1.77 & 5.98 & 19.25 & $\mathrm{Al}_{7} \mathrm{Cu}_{2}(\mathrm{Fe}, \mathrm{Ni})$ \\
59.07 & 4.65 & 1.92 & 0.20 & 1.20 & 32.95 & $\mathrm{Al}_{2} \mathrm{Cu}$ \\
52.23 & 6.37 & 11.37 & - & - & 0.51 & $\mathrm{Mg}_{2} \mathrm{Si}$ \\
\hline
\end{tabular}
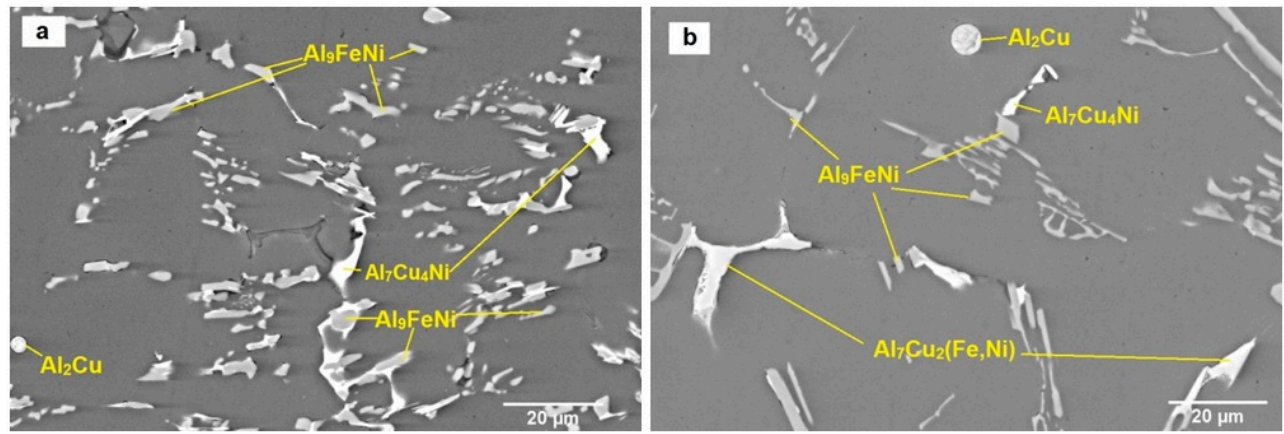

Figure 2. Scanning electron microscope (SEM) images of as-cast microstructure of (a) 2618 and (b) $2618+\mathrm{Zr}$ alloys, showing the morphology of intermetallic particles.

Figure 3 shows the microstructure after solution treatment, consisting in soaking the alloys at $525^{\circ} \mathrm{C}$ for $8 \mathrm{~h}$. This treatment step was applied in order to bring the elements for precipitation-hardening into solid solution, in this case $\mathrm{Cu}$ and $\mathrm{Mg}$, which are present in primary 
coarse particles in the as-cast microstructure. Additionally, precipitation of nanosized Zr-based phases is also supposed to occur during this treatment stage. Table 3 summarizes the chemical composition of intermetallic particles observed in 2618 and $2618+\mathrm{Zr}$ after solution treatment. Due to their resistance to dissolution, even at temperatures as high as $600{ }^{\circ} \mathrm{C}$ [24], Al ${ }_{9} \mathrm{FeNi}$ particles are still present after solution treatment in both 2618 and $2618+\mathrm{Zr}$, however, fragmented with respect to the as-cast condition as a result of the dissolution process. The $\mathrm{Cu}$-containing phases significantly evolved during solution heat treatment: no $\mathrm{Al}_{2} \mathrm{Cu}$ particles were observed after soaking at $525{ }^{\circ} \mathrm{C}$, while only small phases containing $\mathrm{Cu}, \mathrm{Mg}$, and $\mathrm{Ni}$ were observed in the solution-treated samples (Figure 3). This is in agreement with existing literature data [24,25], which report that soaking at temperatures close to $530{ }^{\circ} \mathrm{C}$ leads to dissolution of $\mathrm{Al}_{2} \mathrm{Cu}$ phases and partial solubilization of $\mathrm{Al}_{7} \mathrm{Cu}_{4} \mathrm{Ni}$ particles. $\mathrm{Mg}_{2} \mathrm{Si}$ was still observed, although in a reduced amount, also after solution treatment.
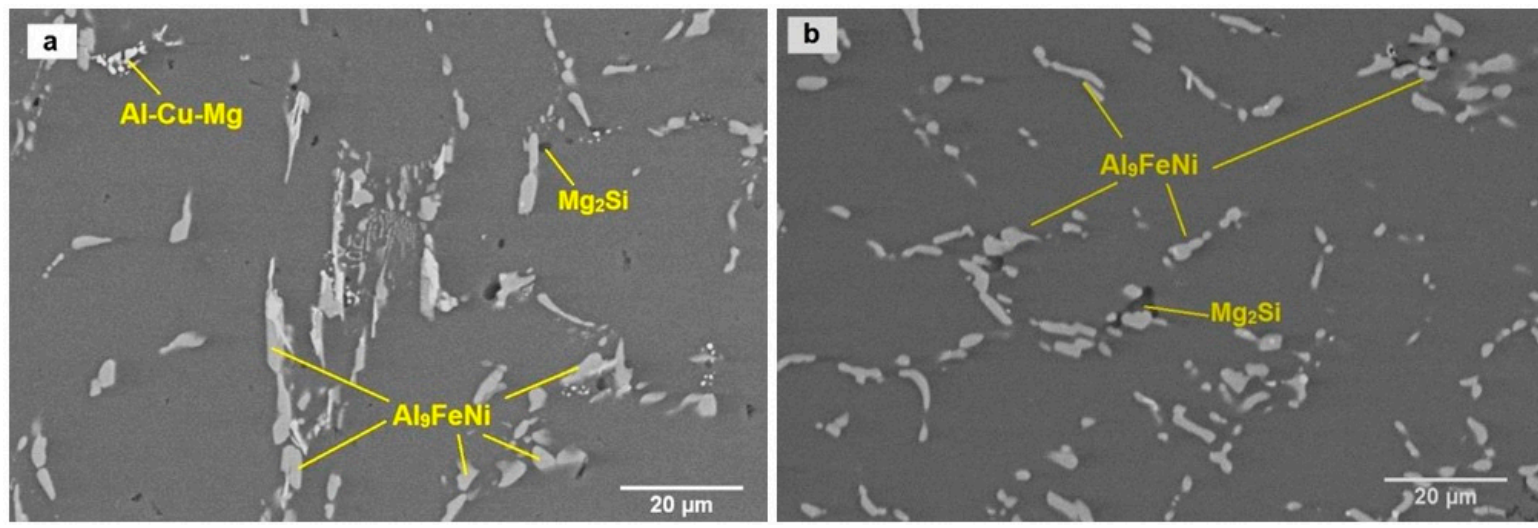

Figure 3. SEM images of solution-treated microstructure of (a) 2618 and (b) $2618+\mathrm{Zr}$ alloys, showing the morphology of intermetallic particles.

Table 3. Chemical composition (atom \%) of intermetallic particles observed on 2618 and $2618+\mathrm{Zr}$ solution treated $\left(8 \mathrm{~h}\right.$ at $\left.525^{\circ} \mathrm{C}\right)$ samples, measured by SEM-EDS.

\begin{tabular}{ccccccc}
\hline Al & $\mathbf{M g}$ & $\mathbf{S i}$ & $\mathbf{F e}$ & $\mathbf{N i}$ & $\mathbf{C u}$ & Suggested \\
\hline 85.93 & 0.71 & 0.72 & 5.66 & 6.03 & 0.94 & $\mathrm{Al}_{9} \mathrm{FeNi}$ \\
78.51 & 0.82 & - & 5.18 & 2.64 & 12.85 & $\mathrm{Al}_{7} \mathrm{Cu}_{2}(\mathrm{Fe}, \mathrm{Ni})$ \\
95.87 & 1.54 & - & 0.35 & 0.22 & 2.02 & $(\mathrm{Al}-\mathrm{Cu}-\mathrm{Mg})$ \\
97.36 & 1.43 & - & - & - & 1.21 & $(\mathrm{Al}-\mathrm{Cu}-\mathrm{Mg})$ \\
50.58 & 9.20 & 10.91 & - & 0.22 & 0.98 & $\mathrm{Mg}_{2} \mathrm{Si}$ \\
\hline
\end{tabular}

The nanoscale microstructure, including precipitates generated during aging treatment and the precipitation of Zr-based phases, was investigated by TEM. Figure 4 shows TEM images of fully overaged $\left(\mathrm{T} 6+192 \mathrm{~h}\right.$ at $\left.300{ }^{\circ} \mathrm{C}\right) 2618$ and $2618+\mathrm{Zr}$ alloys. Large needles growing in the $<001>\mathrm{Al}$ direction, probably corresponding to coarsened $\mathrm{Al}_{2} \mathrm{CuMg}$ ternary S-phases, were observed in the overaged 2618 alloy. Such precipitates, generated by aging treatment, have previously been observed in 2618 alloy [5,28]. Despite coarsening after overaging, the precipitate distribution most likely still exerts significant dislocation pinning. This effect can be observed in Figure 4c, where several dislocations surround one of the precipitate needles. Coarsened S-phases, ranging from $50 \mathrm{~nm}$ to $1 \mu \mathrm{m}$ in length, were observed also in $2618+\mathrm{Zr}$ alloy. In the $2618+\mathrm{Zr}$ alloy, a more even distribution of smaller precipitates was observed compared to the 2618 alloy shown in Figure $4 \mathrm{~b}$. It is likely that the added $\mathrm{Zr}$ may aid in the nucleation of precipitate needles, consequently leading to a higher number density of smaller needles after artificial aging. Further investigations are however needed to fully understand the possible correlation between $\mathrm{Zr}$ addition and $\mathrm{S}$ precipitates distribution. In alloy $2618+\mathrm{Zr}$, small Al-Zr particles were also observed (Figure 4d). Selected area electron diffraction (SAED) was performed on both the aluminum lattice and on the Al-Zr particles, see diffraction patterns in Figure 5. According 
to the indexed diffraction patterns, these particles most likely correspond to fcc trialuminide $\mathrm{Al}_{3} \mathrm{Zr}$, exhibiting the same lattice parameters of the $\mathrm{Al}$ matrix [29]. It should be noted that, despite being overaged, the $\mathrm{Al}_{3} \mathrm{Zr}$ phases maintain an average size of about $10-50 \mathrm{~nm}$.
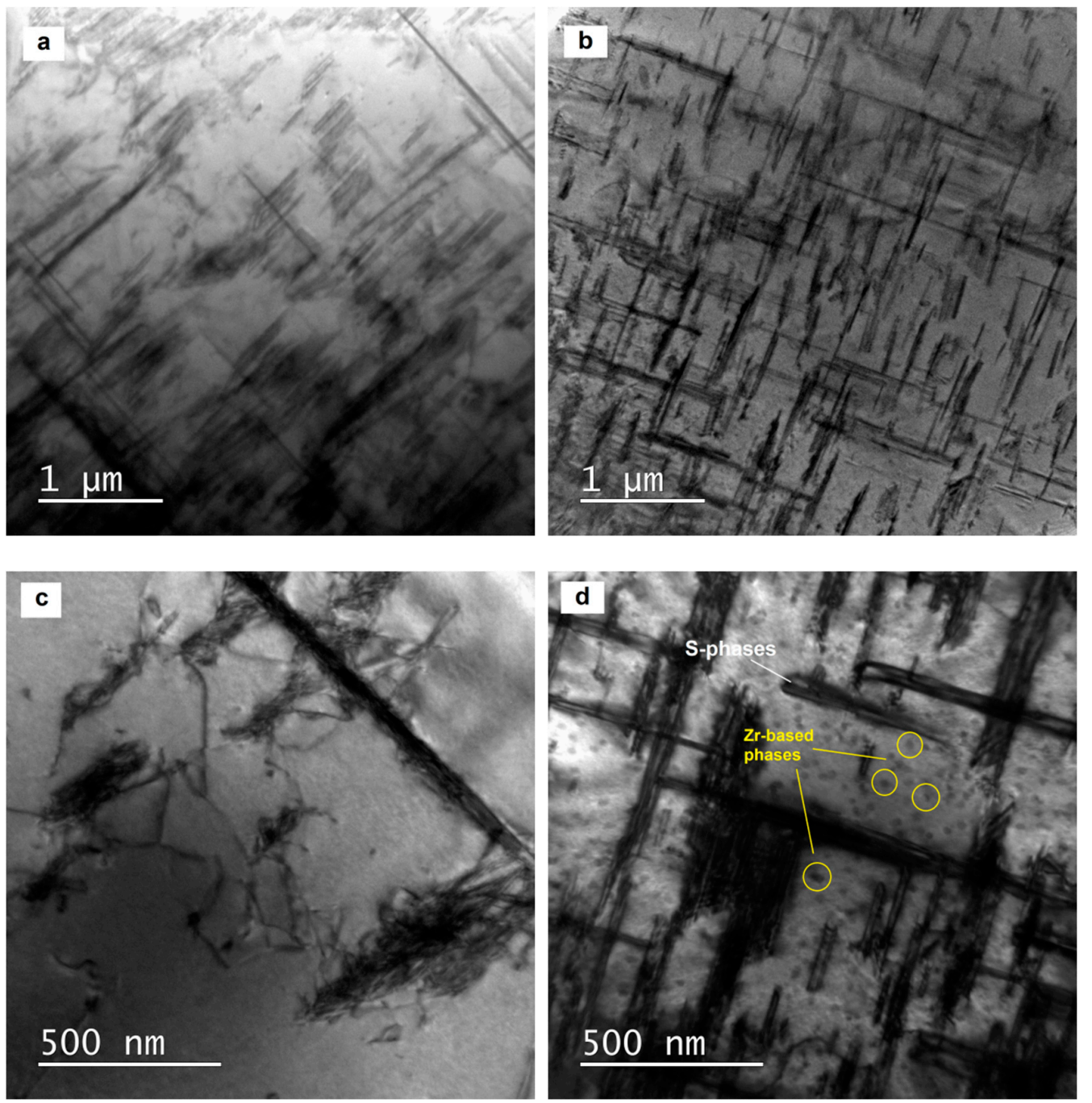

Figure 4. Transmission electron microscopy (TEM) images of 2618 alloy at (a) low and (c) high magnification and $2618+\mathrm{Zr}$ alloy at (b) low and (d) high magnification.
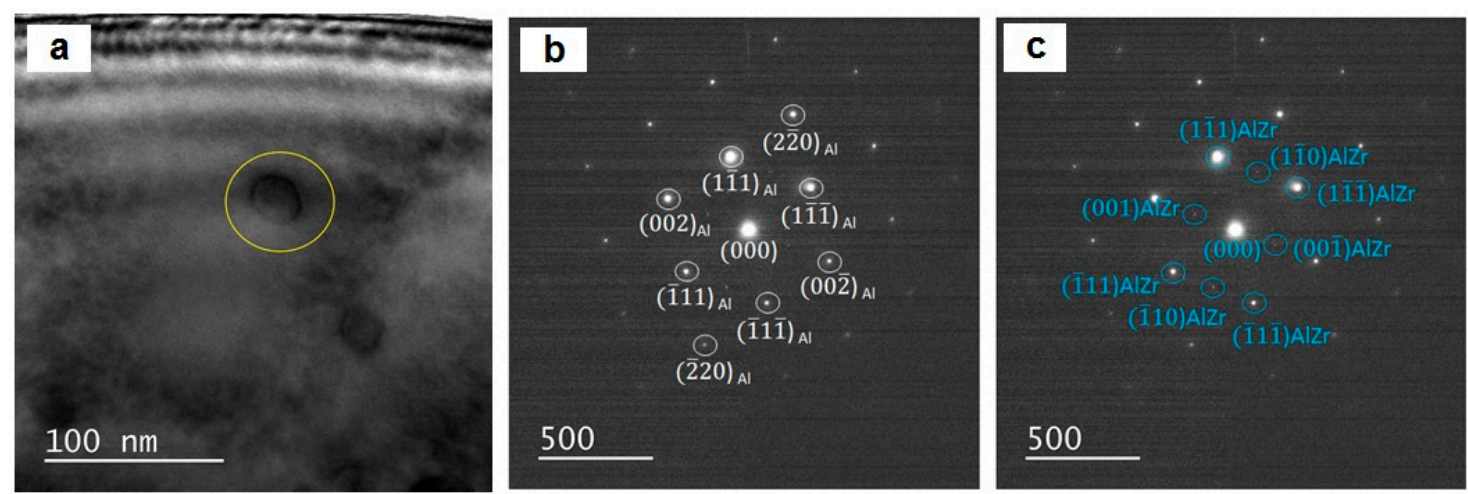

Figure 5. (a) TEM micrograph showing SAED aperture location and $(\mathbf{b}, \mathbf{c})$ SAED patterns of Al matrix and $\mathrm{Al}-\mathrm{Zr}$ particle indicated in (a). 


\subsection{Hardness and Overaging Behavior}

As depicted in Figure 6a, the as-cast 2618 and $2618+\mathrm{Zr}$ alloys are characterized by $102 \pm 2 \mathrm{HB} 10$ and $94 \pm 4$ HB10 hardness, respectively. After T6 heat treatment, similar hardness values were registered in the two alloys, namely $134 \pm 4$ and $131 \pm 3 \mathrm{HB} 10$ for 2618 and $2618+\mathrm{Zr}$, respectively. On the basis of such results, the addition of $\mathrm{Zr}$ to 2618 alloy did not induce appreciable variation of hardness at the $\mathrm{T} 6$ state. No remarkable effects induced by $\mathrm{Zr}$ addition were registered also as concerning the overaging behavior of the alloys: in Figure $6 \mathrm{~b}$, the comparison between overaging curves of the investigated alloys at 250 and $300{ }^{\circ} \mathrm{C}$ is shown. At both temperatures, the curves of 2618 and $2618+\mathrm{Zr}$ are basically superimposed. After soaking for about $22 \mathrm{~h}$, both alloys present a decrease of hardness of about $20 \%$ at $250{ }^{\circ} \mathrm{C}$ and $40 \%$ at $300{ }^{\circ} \mathrm{C}$, as a result of diffusion phenomena and coarsening of $\mathrm{Cu}$ - and $\mathrm{Mg}$-based precipitates induced by high temperature exposure. By increasing overaging time, the hardness of the alloys further decreases, reaching a plateau value regardless of $\mathrm{Zr}$ content, corresponding to about $90 \mathrm{HB} 10$ at $250{ }^{\circ} \mathrm{C}$ and $70 \mathrm{HB} 10$ at $300{ }^{\circ} \mathrm{C}$.
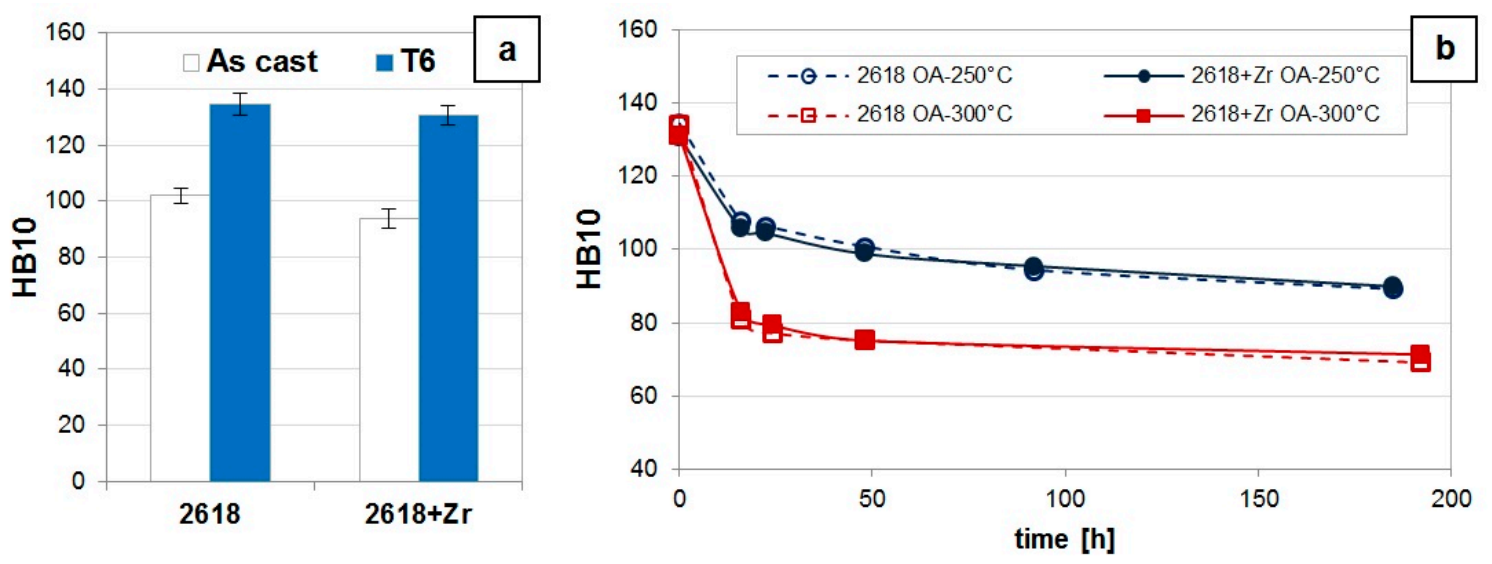

Figure 6. Graphs showing (a) Brinell hardness of the as-cast and T6 heat-treated alloys; (b) overaging curves of 2618 and $2618+\mathrm{Zr}$ alloys, depicting the evolution of hardness from the T6 state with long-term exposure at 250 and $300{ }^{\circ} \mathrm{C}$.

\subsection{Tensile Characterization}

Tensile tests were carried out on overaged alloys, namely soaked at $250{ }^{\circ} \mathrm{C}$ for $48 \mathrm{~h}$, to assess possible effect of $\mathrm{Zr}$ on the tensile behavior of long-term high temperature exposure 2618. Measured tensile properties and the corresponding typical stress-strain curves are summarized in Figure 7. On the basis of these results, a beneficial effect induced by $\mathrm{Zr}$ addition on both ultimate tensile strength (UTS) and yield strength (YS) were registered. At room temperature, an increase of $\sim 7 \%$ and $\sim 22 \%$ was registered for UTS and YS, respectively; also, at $250{ }^{\circ} \mathrm{C}$, a positive effect of $\mathrm{Zr}$ addition was observed, since data revealed an enhancement of $10 \%$ and $12 \%$ for UTS and YS. A consequent reduction of ductility, reflected in a decrease of elongation to failure (El.\%), was observed both at room and high temperature. Since no coarse microstructural appreciable difference was observed between 2618 and $2618+\mathrm{Zr}$, it is thought that the difference in tensile properties is related to the presence of trialuminides observed by TEM analyses. Since the two alloys, both after heat treatment and during overaging, are characterized by the same hardness level, such results could appear incoherent. In fact, it is generally accepted that hardness is directly related to tensile properties, in particular to YS, both being strictly connected to dispersed nanometric strengthening phases. To explain this issue, it should be taken into account that, as documented for other alloys types such as Al-Si casting alloys, the level of local strain hardening of the material during the indentation is influenced by the presence of different precipitates in terms of both composition and/or morphology. The different local strain hardening behavior of the material leads to different indentation morphology, as results from a linear hardness-yield strength relationship do not always fit experimental data [30,31]. In order to 
take this aspect into account, relationships between hardness and strength should also consider the strain hardening exponent $n$. In view of this, 2618 and $2618+Z$ r overaged alloys present significantly different yield strength, despite comparable hardness, probably as a result of the strengthening effect induced by $\mathrm{Al}_{3} \mathrm{Zr}$ trialuminides. No relevant difference in the morphology of fracture surfaces was observed between 2618 and $2618+\mathrm{Zr}$ alloys at both room and high temperature (Figure 8); all the fracture surfaces are characterized by small-sized and homogeneously distributed dimples, which developed around fine intermetallic particles, typical of ductile fracture morphology.
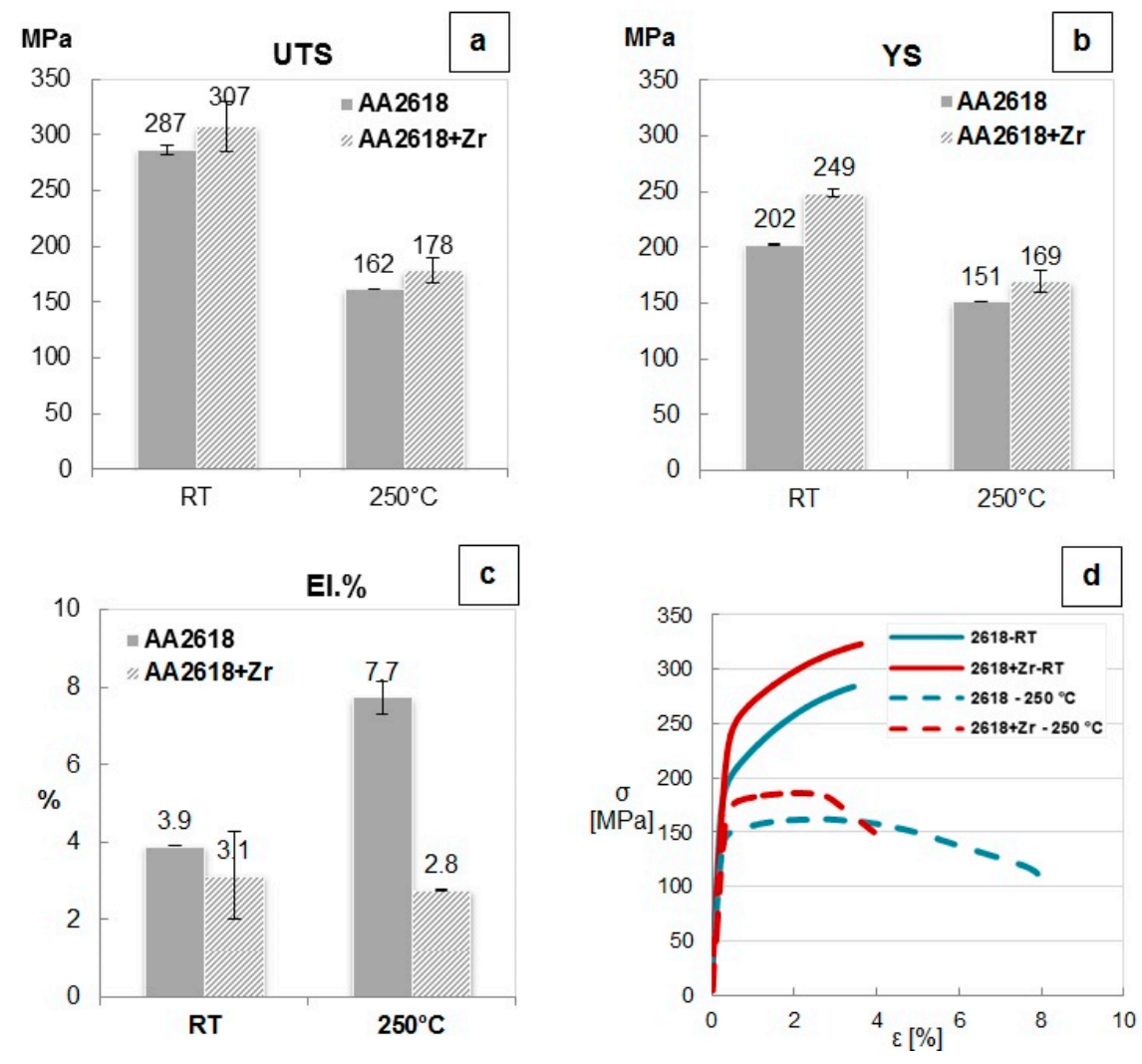

Figure 7. Tensile properties at room temperature and $250{ }^{\circ} \mathrm{C}$ of the overaged (i.e., $\mathrm{T} 6+48 \mathrm{~h}$ at $250{ }^{\circ} \mathrm{C}$ ) 2618 and $2618+$ Zr alloys: (a) ultimate tensile strength, UTS, (b) yield strength, YS, and (c) elongation to failure, El.\%; (d) representation of typical stress-strain curves for the investigated alloys.
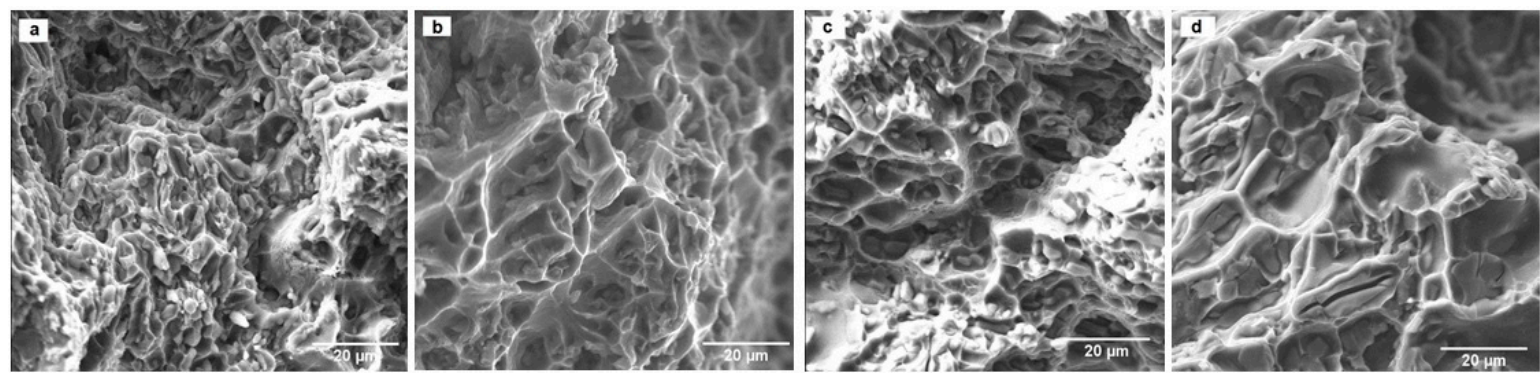

Figure 8. Fracture surfaces of overaged 2618 alloy tensile tested at (a) room temperature and (b) $250{ }^{\circ} \mathrm{C}$; fracture surfaces of $2618+\mathrm{Zr}$ alloy of samples tested at (c) room temperature and (d) $250{ }^{\circ} \mathrm{C}$.

\section{Conclusions}

The present work was aimed to study the effect of $\mathrm{Zr}$ addition to 2618 high performance piston aluminum alloy, in particular, in enhancing the thermal resistance of the alloy. Castings of 2618 and $2618+\mathrm{Zr}$ alloys were produced. Cast samples were heat-treated according to T6 industrial practice; 
overaging and tensile behavior of the alloys were investigated by coupling mechanical characterization to microstructural investigation. On the basis of the experimental results, the following conclusions were drawn.

In these experimental conditions, no effect induced by $\mathrm{Zr}$ addition was registered on microstructure of the alloys in terms of coarse primary intermetallics compounds; similarly, no relevant effect on hardness and overaging behavior was observed: 2618 and $2618+\mathrm{Zr}$ alloys presented basically the same hardness after T6 heat treatment, and presented the same overaging curves at 250 and $300{ }^{\circ} \mathrm{C}$.

As a result of TEM analyses in a fully overaged condition, nanometric particles were observed in the $\mathrm{Zr}$-enriched alloy, probably $\mathrm{Al}_{3} \mathrm{Zr}$ trialuminides, which are thought to nucleate during solution treatment.

Despite that no effect on hardness and overaging behavior was observed by adding $\mathrm{Zr}$, a not negligible increase of tensile properties was registered both at room temperature and at $250{ }^{\circ} \mathrm{C}$ in the overaged condition $\left(48 \mathrm{~h}\right.$ at $\left.250{ }^{\circ} \mathrm{C}\right)$. It is thought this is related to the presence of trialuminides observed by TEM analyses, but the mechanisms involved in the increase of tensile strength while maintaining similar hardness values need further investigation for full comprehension.

Author Contributions: Conceptualization, methodology and investigation E.B., S.T. and E.A.M.; writing—original draft preparation, S.T.; review and editing, all the authors; supervision, L.C., A.M., M.D.S.

Funding: This research received no external funding.

Acknowledgments: The authors gratefully acknowledge Duraldur SpA (Desenzano del Garda, Italy) for providing 2618 alloy to perform the experimental activities.

Conflicts of Interest: The authors declare no conflict of interest.

\section{References}

1. Cantore, G.; Giacopini, M.; Rosi, R.; Strozzi, A.; Pelloni, P.; Forte, C.; Achiluzzi, M.; Bianchi, G.M.; Ceschini, L.; Morri, A. Validation of a combined CFD/FEM methodology for the evaluation of thermal load acting on aluminum alloy pistons through hardness measurements in internal combustion engines. Met. Sci. Technol. 2011, 29, 16-25.

2. Miers, S.A.; Anderson, C.L.; Blough, J.R.; Inal, M.K. Impingement identification in a high speed diesel engine using piston surface temperature measurements. SAE Tech. Pap. 2005, 1, 1909. [CrossRef]

3. Hatch, J. Properties of Commercial Wrought Alloys. In Aluminium: Properties and Physical Metallurgy; ASM International; American Society for Metals: Metals Park, OH, USA, 1984.

4. Wilson, R.N.; Forsyth, P. Effects of dditions of 1\% Iron and 1\% Nickel on age-hardening of an Aluminum-2.5\% Copper-1.2\% Magnesium alloy. J. Inst. Met. 1966, 94, 8-13.

5. Novy, F.; Janecekb, M.; Král, R. Microstructure changes in a 2618 aluminium alloy during aging and creep. J. Alloys Compd. 2009, 487, 146-151. [CrossRef]

6. Cho, Y.H.; Joo, D.H.; Kim, C.H.; Lee, H.C. The Effect of Alloy Addition on the High Temperature Properties of Over-Aged Al-Si(CuNiMg) Cast Alloys. Mater. Sci. Forum. 2006, 519-521, 461-466. [CrossRef]

7. Knipling, K.E.; Dunand, D.C.; Seidman, D.N. Criteria for developing castable, creep-resistant aluminum-based alloys-A review. Zeitschrift Für Met. 2006, 97, 246-265. [CrossRef]

8. Kasprzak, W.; Amirkhiz, B.S.; Niewczas, M. Structure and properties of cast Al-Si based alloy with Zr-V-Ti additions and its evaluation of high temperature performance. J. Alloys Compd. 2014, 595, 67-79. [CrossRef]

9. Zhang, J.; Ding, D.; Zhang, W.; Kang, S. Effect of Zr addition on microstructure and properties of Al-Mn-Si-Zn-based alloy. Trans. Nonferrous Met. Soc. China 2014, 24, 3872-3878. [CrossRef]

10. Shaha, S.K.; Czerwinski, F.; Kasprzak, W.; Friedman, J.; Chen, D.L. Thermal stability of (AlSi)x(ZrVTi) intermetallic phases in the Al-Si-Cu-Mg cast alloy with additions of Ti, V, and Zr. Thermochim. Acta 2014, 595, 11-16. [CrossRef]

11. Shaha, S.K.; Czerwinski, F.; Kasprzak, W.; Friedman, J.; Chen, D.L. Effect of Zr, V and Ti on hot compression behavior of the Al-Si cast alloy for powertrain applications. J. Alloys Compd. 2014, 615, 1019-1031. [CrossRef]

12. Rakhmonov, B.J.; Timelli, G.; Bonollo, F. The Effect of Transition Elements on High-Temperature Mechanical Properties of Al-Si Foundry Alloys-A Review. Adv. Eng. Mater. 2016, 18, 1096. [CrossRef] 
13. Zedalis, M.S.; Fine, M.E. Precipitation and ostwald ripening in dilute Al Base-Zr-V alloys. Met. Mater. Trans. A 1986, 17, 2187-2198. [CrossRef]

14. Totten, G.E.; MacKenzie, D.S. Handbook of Aluminum-Volume 2: Alloy Production and Materials Manufacturing; CRC Press: Boca Raton, FL, USA, 2003.

15. Knipling, K.E.; Dunand, D.C.; Seidman, D.N. Precipitation evolution in Al-Zr and Al-Zr-Ti alloys during aging at $450-600^{\circ} \mathrm{C}$. Acta Mater. 2008, 56, 1182-1195. [CrossRef]

16. Knipling, K.; Dunand, D.C. Creep resistance of cast and aged Al-0.1Zr and Al-0.1Zr-0.1Ti (at.\%) alloys at 300-400 C. Scr. Mater. 2008, 59, 387-390. [CrossRef]

17. Knipling, K.E.; Seidman, D.N.; Dunand, D.C. Ambient- and high-temperature mechanical properties of isochronally aged Al-0.06Sc, Al-0.06Zr and Al-0.06Sc-0.06Zr (at.\%) alloys. Acta Mater. 2011, 59, 943-954. [CrossRef]

18. Booth-Morrison, C.; Dunand, D.C.; Seidman, D.N. Coarsening resistance at $400{ }^{\circ} \mathrm{C}$ of precipitation-strengthened Al-Zr-Sc-Er alloys. Acta Mater. 2011, 59, 7029-7042. [CrossRef]

19. Vo, N.Q.; Dunand, D.C.; Seidman, D.N. Improving aging and creep resistance in a dilute Al-Sc alloy by microalloying with $\mathrm{Si}, \mathrm{Zr}$ and Er. Acta Mater. 2014, 63, 73-85. [CrossRef]

20. Ceschini, L.; Morri, A.; Morri, A.; Di Sabatino, M. Effect of thermal exposure on the residual hardness and tensile properties of the EN AW-2618A piston alloy. Mater. Sci. Eng. A 2015, 639, 288-297. [CrossRef]

21. ASM International. ASTM E 10-08 Standard Test Method for Brinell Hardness of Metallic Materials; ASM International: West Conshohocken, PA, USA, 2007.

22. International Organization for Standardization. ISO 6892-1:2009, Metallic Materials-Tensile Testing-Part 1: Method of Test at Room Temperature; International Organization for Standardization: Geneva, Switzerland, 2009.

23. International Organization for Standardization. ISO 6892-2:2011, Metallic Materials-Tensile Testing-Part 2: Method of Test at Elevated Temperature; International Organization for Standardization: Geneva, Switzerland, 2011.

24. Elgallad, E.M.; Shen, P.; Zhang, Z.; Chen, X. Effects of heat treatment on the microstructure and mechanical properties of AA2618 DC cast alloy. Mater. Des. 2014, 61, 133-140. [CrossRef]

25. Shen, P.; Elgallad, E.M.; Chen, X.G. On the aging Behavior of AA2618 DC cast alloy. In Light Metals 2013; The Minerals, Metals \& Materials Series; Sadler, B.A., Ed.; Springer: Cham, Switzerland.

26. Oguocha, I.N.; Yannacopoulos, S.; Jin, Y. The structure of AlxFeNi phase in Al-Cu-Mg-Fe-Ni alloy (AA2618). J. Mater. Sci. 1996, 31, 5615-5621. [CrossRef]

27. Moreau, E.; Donaldson, I.W.; Hexemer, R.; Bishop, D. Effects of Fe and Ni additions on PM alloy. Part 2-Influence of elevated temperature exposure. Can. Metall. Q. 2013, 52, 380-390. [CrossRef]

28. Lu, H.; Kadolkar, P.; Nakazawa, K.; Ando, T.; Blue, C. Precipitation Behavior of AA2618. Metall. Mater. Trans. A 2007, 38, 2379-2388. [CrossRef]

29. Lefebvre, W.; Masquelier, N.; Houard, J.; Patte, R.; Zapolsky, H. Tracking the path of dislocations across ordered Al3Zr nano-precipitates in three dimensions. Scr. Mater. 2014, 70, 43-46. [CrossRef]

30. Tiryakioğlu, M.; Campbell, J.; Staley, J. On macrohardness testing of Al-7 wt. Si-Mg alloys 2-An evaluation of models for hardness-yield strenght relationship. Mater. Sci. Eng. A 2003, 361, 240-248. [CrossRef]

31. Warren, A.; Campbell, J. The Metallurgy of Light Alloys. In Proceedings of the Metallurgy of Light Alloys: Spring Residential Conference, Loughborough, UK, March 1983; pp. 195-207.

(C) 2019 by the authors. Licensee MDPI, Basel, Switzerland. This article is an open access article distributed under the terms and conditions of the Creative Commons Attribution (CC BY) license (http://creativecommons.org/licenses/by/4.0/). 